\section{Roche fails to get European patent on Taq polymerase}

London. The European Patent Office (EPO) has rejected a claim from pharmaceutical company Hoffman-La Roche for a patent on the naturally occurring version of the thermostable enzyme Taq polymerase, used in laboratories throughout the world in the polymerase chain reaction (PCR) process to amplify small amounts of DNA.

In a letter to the company, the patent office suggests it can find no significant difference between the Taq described in the patent application, which was first submitted in 1987, and that resulting from experiments carried out at the University of Cincinnati in 1976 (see Nature 373, 377; 1995).

Some observers believe that the decision, if it survives an appeal, could eventually lead to a significant fall in the cost of Taq throughout Europe as, although the enzyme is widely believed to cost less than 20 US cents a unit to produce, suppliers which have signed a licensing deal with Roche are said to have to pay a further 16 cents to the Swiss-based company.

It could also have an impact in the United States. Although Taq has been patented there by Roche, this patent is already being challenged by the laboratory supply company Promega, in a case which is due to go to trial in San Francisco in the near future.

Carolyn Sutter, a spokeswoman for Roche, says that the company does not see any necessary connection with the US case, which follows a charge brought by the company against Promega for unlicensed sales of Taq. "It is a completely different legal situation" in the United States to that in Europe, she says.

Sutter says that Roche is planning to challenge the arguments put forward by the EPO examiner in rejecting the European patent application, and is discussing the next step with its lawyers. "We believe in the patentability of this invention," she says.

But Bill Linton, chief executive officer of Promega, disagrees. "The EPO has recognized the strength of the 1976 prior art in denying Roche's nine-year attempt to obtain the nTaq patent," he says. "The US District Court in San Francisco is looking at the same evidence, and we believe it will reach the same conclusion - nTaq should not have been patented."

Roche obtained the rights to the potential Taq patent as part of a $\$ 300$-million deal in 1991 with US company Cetus for the rights to PCR, a technique invented by the Nobel laureate Kary Mullis that has revolutionized the analysis of DNA samples.

Although the validity of the PCR patent has not been challenged, the Taq patent has long been controversial, both because of licensing fees reported as being demanded by Roche, and also because Taq is a naturally occurring enzyme extracted from the bacterium Thermus aquaticus found living in hot springs (the company already has a patent on recombinant Taq, which is not under dispute).

Roche has actively pursued companies discovered to be selling Taq without a licence, and has persuaded large users of the enzyme, such as Britain's Medical Research Council (MRC) and its Biotechnology and Biological Sciences Research Council, only to deal with licensed suppliers, at least until the patent issue is settled.

Two years ago, in what now turns out to have been a premature move, Roche announced that it had been told by the patent office that the patent would be granted. But its confidence was misplaced. The examiner subsequently notified the company that, in view of objections raised

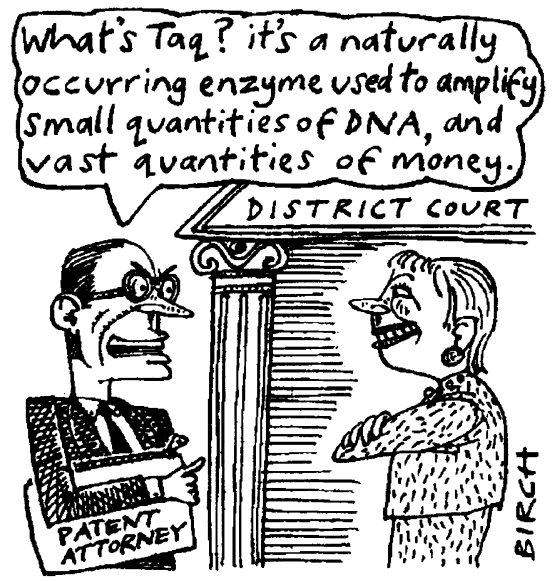

(one of the most prominent challengers being Promega), it required further evidence that the Taq described in the patent application had not already been discovered (see Nature 374, 108; 1995).

The company's response was that, first, the Cincinnati scientists had described an enzyme with molecular weight significantly different from its own and, second, that Roche's enzyme was much more effective in faithfully duplicating DNA sequences. The patent examiner has not been convinced, and has informed Roche that her original objections to the patent "still apply".

The next legal step open to Roche is to appeal against this decision to a threemember appeals board set up by the EPO. If this overturns the examiner's ruling, then the patent will be granted. If the appeal fails - and even if companies currently producing Taq under licence have difficulty in changing the terms of their agreements with Roche - others will be free to sell products based on naturally occurring Taq without paying royalties.

\section{US panel established to coordinate work on endocrine disrupters}

Washington. The Clinton administration has established a panel to improve the coordination of research into the effects of endocrine disrupters, the man-made chemicals whose presence in the environment may be disrupting human reproduction and development by interfering with hormone levels.

The high-level panel - a working group of the environmental subcommittee of President Bill Clinton's National Science and Technology Council (NSTC) - will bring together scientists from a dozen federal agencies to establish the scope of existing work on endocrine disrupters, and to fill gaps in the programme.

The panel starts its work amid considerable controversy in the United States about the publication of a book, Our Stolen Future, by Theo Colburn and Dianne Dumanoski, which argues that the chemicals constitute an urgent public health threat. The book, which has a foreword by Vice-President Al Gore, has been attacked by industry groups and scientists who say that the threat is, at best, unproven.

But Bob Kavlock, a panel member and a leading toxicologist at the Environmental Protection Agency (EPA), says the research is justified, whether the threat is proven or not, because its potential impact is so serious. "If it affects reproduction, it has fairly big implications," says Kavlock, citing the current scientific dispute about sperm counts in American men as an example. "If human sperm counts really have declined by half over the last $\mathbf{4 0}$ years, we need to know about it now - we can't wait another 40 years to find out," he says.

Kavlock, who is director of the reproductive toxicology division at the EPA's National Health and Environmental Effects Research Laboratory at Research Triangle Park, North Carolina, says that the panel is starting work by developing a summary of research needs in key areas. These include methods to detect the presence of the chemicals and their effects, and models to extrapolate available data to show the likely impact on public health.

The panel will also prepare an inventory of existing programmes in each of the agencies, as well as surveying work under way outside the United States, before assessing how well the work fits research needs.

The EPA currently spends almost $\$ 10$ million a year on endocrine disrupter research, which it has been studying (under various names) for 20 years. The size of the total federal effort is unknown, but could well increase as a result of Gore's interest and the activities of the NSTC panel.

Colin Macilwain 